\title{
Diminished expression of ICOS, GITR and CTLA-4 at the mRNA level in $T$ regulatory cells of children with newly diagnosed type 1 diabetes
}

\author{
Włodzimierz Łuczyński ${ }^{1 凶}$, Natalia Wawrusiewicz-Kurylonek ${ }^{2}$, \\ Anna Stasiak-Barmuta ${ }^{3}$, Remigiusz Urban ${ }^{4}$, Elżbieta Iłendo $^{5}$, Mirosława Urban ${ }^{1}$, \\ Marek Hryszko ${ }^{5}$, Adam Krętowski ${ }^{2}$ and Maria Górska ${ }^{2}$ \\ ${ }^{1}$ IInd Department of Pediatrics, ${ }^{2}$ Department of Endocrinology, Diabetology and Internal Medicine, \\ ${ }^{3}$ Department of Clinical Immunology, ${ }^{4}$ Department of Perinatology and ${ }^{5}$ Department of Cytogenetics, \\ Medical University of Białystok, ${ }^{6}$ The Voivodalship Specialistic Hospital, Biatystok, Poland
}

Received: 16 April, 2009; revised: 09 June, 2009; accepted: 18 June, 2009 available on-line: 20 June, 2009

\begin{abstract}
Diabetes mellitus is one of the most common chronic diseases in children. $T$ regulatory cells (Tregs) modulate response to autoantigens and probably play a role in pathogenesis of type 1 diabetes (T1DM). The aim of the present study was the assessment of $T$ regulatory cells including their percentages and expression of critical genes in these cells in children with newly diagnosed type 1 diabetes. The examined group consisted of 50 children with T1DM. A flow cytometric analysis of T-cell subpopulations was performed using the following markers: anti-CD4, anti-CD25 and anti-CD127 (=IL-7R). Additionally, T regulatory cells were isolated for assessment of mRNA levels for chosen genes with the real-time RT-PCR technique. The percentages of $\mathrm{CD} 4^{+} \mathrm{CD} 25^{\text {high }} \mathrm{CD} 127^{\mathrm{dim} /-}$ were very low and did not differ between T1DM and control children. We did not observe any statistically significant differences between healthy and diabetic children in mRNA expression for FoxP3, IL-7R (CD127), IL-8RA, IL-10RA, IL-12A, IL-2RA (CD25), IL-21, STAT1, STAT3, SOCS2, SOCS3, TGF- $\beta 1-R 1$, TGF- $\beta-R 2$ and TBX-21 genes. Interestingly the mRNA level for CTLA-4, ICOS1, IL-23, IL-27, SMAD3 and GITR were lower in Treg cells of children with diabetes compared to the control patients. No disturbances in the percentages of $T$ regulatory cells in patients with diabetes but diminished expression of some elements important in Treg function could be the result of an immunologic imbalance accompanying the onset of the diabetes. The results of our study should be used in future research in the field of immunotherapy in pediatric diabetes.
\end{abstract}

Keywords: immunotherapy, autoimmunity, T-lymphocytes, FoxP3

\section{INTRODUCTION}

Type 1 diabetes mellitus (T1DM) is one of the most common chronic diseases in children. Most of the cases of T1DM presenting at this age have an autoimmune basis: the destruction of pancreatic beta cells caused by cytotoxic lymphocytes followed by the deficit of insulin and symptoms of hyperglycemia. Its long-term complications including cardio- vascular disease, blindness and kidney failure can be devastating. A novel therapy based on immunopathogenesis is desperatively needed in this incurable disease. The breakdown of beta cell-specific self-tolerance by $\mathrm{T}$ lymphocytes involves a number of dysregulated events intrinsic and extrinsic to $\mathrm{T}$ cells. The peripheral tolerance to self antigens is maintained through several regulatory mechanisms, including $\mathrm{T}$ regulatory cells. $\mathrm{T}$ regulatory cells mod-

\footnotetext{
${ }^{\triangle}$ Corresponding author: Włodzimierz Łuczyński, II ${ }^{\text {nd }}$ Department of Pediatrics, Medical University, 15-274 Białystok Waszyngtona 17, Poland; phone/fax: (48) 85745 0730; e-mail: w.luczynski@wp.pl

Abbreviations: ATRA, all-trans retinoic acid; CTLA-4, cytotoxic T lymphocyte antigen-4; GITR, glucocorticoid-induced TNF receptor related protein; ICOS, inducible T-cell costimulator; NOD mice, nonobese diabetic mice; T1DM, type 1 diabetes mellitus; T-bet, T-box expressed in T cells; Tregs, T regulatory cells; STAT, signal transducer and activator of transcription factor; SOCS, suppressor of cytokine signalling.
} 
ulate a response to autoantigens and probably play a role in pathogenesis of type 1 diabetes (reviewed by: Bluestone et al., 2008). To date, several subtypes of $\mathrm{T}$ regulatory cells have been described, including natural $\mathrm{CD}^{+}{ }^{+}$Tregs, $\mathrm{Th}_{3}, \mathrm{Tr}_{1}$ and $\mathrm{CD} 8^{+}$Treg cells. Natural Tregs are developed primarily in the thymus, represent $5-10 \%$ of the total $\mathrm{CD} 4^{+}$population and express CD4, CD25 antigens and the transcription factor FoxP3. $\mathrm{Tr}_{1}$ and $\mathrm{Th}_{3}$ cells can develop in the periphery and have been shown to secrete IL-10 and TGF- $\beta$, respectively. Little is known about $\mathrm{CD}^{+}$ Tregs.

The naturally occurring Tregs except for high CD25 and FoxP3 expression can be characterized by the presence of additional markers: CTLA-4 (CD152), GITR, ICOS, OX40, 4-1BB and low amounts of IL7R (CD127) (Friedline et al., 2009). There is a lack of consensus regarding the definition of cell-surface antigens characteristic of $\mathrm{T}$ regulatory cells: $\mathrm{CD} 4^{+}$ and $\mathrm{CD} 25^{+}$cells were previously indicators of Tregs, however, some studies suggested that only cells expressing the highest levels of CD25 expose in vitro suppressive activity. Although FoxP3 is constitutively expressed in Treg cells, it is also present in activated $\mathrm{T}$ cells, jeopardizing its Treg specificity (Roncador et al., 2005). Recent research from two laboratories has demonstrated that CD127 ( $\alpha$-chain of the interleukin-7 receptor) expression is down-regulated on human $\mathrm{T}$ cells after activation (Liu et al., 2006; Seddiki et al., 2006). Low or negative cell surface expression of CD127 antigen provides a flexible alternative to the FoxP3 for identifying and isolating $\mathrm{T}$ regulatory cells for functional analysis (Seddiki et al., 2006). The $\mathrm{CD} 4^{+} \mathrm{CD} 25^{+} \mathrm{CD} 127^{- \text {llow }}$ cells are considered to be $\mathrm{T}$ regulatory cells.

The suppressive capacities of Tregs result from not fully understood signalling pathways involving various receptors and cytokines and seems to depend more on the cell-cell contact than on cytokines. The function of Tregs depends on intracellular signalling including numerous transcription factors, pro- and anti-inflammatory cytokine receptors and other molecules like GITR, ICOS, CTLA-4 (Fife \& Bluestone, 2008). Very little is known about the production of cytokines by $\mathrm{CD} 44^{+} \mathrm{CD} 25^{\text {high }} \mathrm{FoxP}^{+}$ $\mathrm{T}$ regulatory cells. Probably both - pro- and anti-inflammatory cytokines take part in the phenomenon of peripheral tolerance. IL-21 is a modulator of the adaptive immune response, a constituent in models of such autoimmune diseases like type 1 diabetes. The Tregs suppression can be subverted by IL-21 (Clough et al., 2008). IL-27, a member of the IL-12, family, can both promote anti- and pro-inflammatory immune responses. IL-27 and TGF- $\beta$ promote the generation of IL-10 producing T cells. IL-27 inhibits the Tregs function including FoxP3, CD25 and CTLA-4 expression. The mechanism of its ac- tion probably involves STAT-3 (Huber et al., 2008). In contrast, the STAT- 1 signal and TGF- $\beta$ induce the suppressive phenotype. IL-35 is a novel cytokine composed of EBV-induced gene 3 (EBI3) and p35 subunit of IL-12. In mice, IL-35 is involved in Tregs function. The evidence of the role of IL-12, IL-21 and IL-27 in autoimmune inflammation has been investigated for a few years, but IL-35 has only recently been described.

Although cellular responses to cytokines are tightly controlled, a few molecules have been identified which are able to switch these signals off. The suppressors of cytokine signalling (SOCS) proteins are a new family of negative regulators of cytokine signal transduction. SOCS proteins control many aspects of lymphocyte function through regulation of signal transducers and activators of transcription (STAT) pathways. Recent studies have shown that STAT can interface with SMAD and some novel molecules, such as SOCS at the molecular level. Proteins like T-bet, STAT and SOCS are involved in modulation and alterations in the balance of inflammatory and regulatory pathways. SOCS- 3 is an essential negative regulator of IL-23 signalling (Chen et al., 2006; Matsumura et al., 2007).

The low frequency and unknown specificity of Tregs represent major obstacles to their diagnostic and therapeutic use. The activity of these cells plays a central role in preventing pathogenic immune responses against self-antigens and could be used as a therapeutic tool in autoimmune disorders. Impaired functional activity of $\mathrm{T}$ regulatory cells has been reported in diabetic patients (Lindley et al., 2005). As far as we know the previous studies did not concern the expression of genes in separated $\mathrm{CD} 4^{+} \mathrm{CD} 25^{+} \mathrm{CD} 127^{\text {low/- }}$ cells. The aim of the present study was the assessment of $\mathrm{T}$ regulatory cells including their percentages and expression of critical genes in these cells in children with newly diagnosed type 1 diabetes. With the use of flow cytometry and real-time RT-PCR we report similar percentages of $\mathrm{T}$ regulatory cells in children with T1DM compared to the healthy subjects but lower expression of important genes in Treg function like ICOS, CTLA-4 and GITR. These results indicate the possible mechanism of their dysfunction and the basis for further research in this field.

\section{PATIENTS}

The examined group consisted of 50 children with T1DM. Fifty two healthy individuals (control group) were enrolled into the study. The children from control group had no signs of autoimmune, chronic, inflammatory, neoplasmatic disease and negative family history for T1DM (no differences 
Table 1. Clinical data regarding patients from examined and control groups (number or mean \pm S.D.)

\begin{tabular}{lcllllll}
\hline Group & $\mathrm{N}$ & $\begin{array}{l}\text { Gender } \\
\text { (male/ } \\
\text { female) }\end{array}$ & $\begin{array}{l}\text { Age } \\
\text { (years) }\end{array}$ & $\begin{array}{l}\text { Duration of } \\
\text { the disease } \\
\text { (weeks) }\end{array}$ & $\begin{array}{l}\text { Glycated hemo- } \\
\text { globin HbA1c }(\%)\end{array}$ & $\begin{array}{l}\text { Insulin intake } \\
\text { (units/kg } \\
\text { per day) }\end{array}$ & General condition \\
\hline $\begin{array}{l}\text { Healthy control } \\
\text { subjects }\end{array}$ & 52 & $28 / 24$ & $11.9 \pm 3.1$ & - & $5.5 \pm 0.4$ & - & good $-52(100 \%)$ \\
$\begin{array}{l}\text { Type 1 diabetes } \\
\text { mellitus }\end{array}$ & 50 & $24 / 26$ & $10.9 \pm 4.4$ & $4 \pm 1.3$ & $10.1 \pm 1.3$ & $0.8 \pm 0.2$ & $\begin{array}{l}\text { good }-21(42 \%) \\
\text { reduced }-20(40 \%) \\
\text { coma }-9(18 \%)\end{array}$ \\
\hline
\end{tabular}

in sex and age compared to the examined group, $P>0.05)$. Clinical characteristics of examined and control groups are presented in Table 1 . Type 1 diabetes was diagnosed according to the American Diabetes Association criteria (2008). The peripheral blood was collected after achieving the metabolic balance, 24 to 35 days from the diagnosis/start of insulin treatment. The blood samples from the patients and controls were obtained under the protocols approved by the Medical University of Bialystok institutional review board. An informed consent was given by the participating children and their parents.

\section{METHODS}

Flow cytometry. Mononuclear cells were isolated from peripheral blood by centrifugation over Histopaque (Sigma). A flow cytometric analysis of T-cell subpopulations was performed using the following markers: anti-CD3 (phycoerythrin-cyanin 5 PECy5 conjugated, UCHT1 clone), anti-CD4 (phycoerythrin-cyanin 7 PECy7 conjugated, SFCI12T4D11 clone), anti-CD25 (fluorescein isothiocyanate, FITC, conjugated, B1.49.9 clone) and anti-CD127 (=IL-7R, phycoerythrin conjugated PE, R34.34 clone) purchased from Beckman Coulter (USA). Respective isotype control antibodies were used. The samples were analysed by 5-colour flow cytometer Beckman Cytomics FC 500 MPL using CXP software ver. 2.0 (Beckman Coulter, USA). A minimum of $10^{5}$ events was aquired for each analysis. The percentages of positive cells were calculated. To determine absolute cell counts, a small volume of blood was analyzed for complete blood count (CBC) with a differential. The absolute counts were determined by multiplying the frequency of positive cells determined in cytometric analysis by the number of lymphocytes [G/l] as determined by CBC.

Cell separation. $\mathrm{T}$ regulatory cells were isolated from mononuclear cells according to the producer's instruction (Miltenyi Biotec, Germany). The isolation of $\mathrm{CD} 4^{+} \mathrm{CD} 25^{+} \mathrm{CD} 127^{\mathrm{dim} /-}$ regulatory $\mathrm{T}$ cells was performed in a two-step procedure. First, non-CD $4^{+}$ and $\mathrm{CD} 127^{\text {high }}$ cells were indirectly magnetically labeled with a cocktail of biotin-conjugated antibodies and anti-biotin MicroBeads. The labeled cells were subsequently depleted by separation over a MACS® Column. In the second step, CD $4^{+} \mathrm{CD} 25^{+} \mathrm{CD} 127^{\mathrm{dim} /-}$ regulatory $\mathrm{T}$ cells were directly labeled with $\mathrm{CD} 25$ MicroBeads and isolated by positive selection from the pre-enriched $\mathrm{CD}^{+} \mathrm{T}$ cell fraction. After removing the column from the magnetic field, the magnetically retained $\mathrm{CD} 4^{+} \mathrm{CD} 25^{+} \mathrm{CD} 127^{\mathrm{dim} /-}$ regulatory $\mathrm{T}$ cells were eluted as the positively selected cell fraction. To increase the purity, the positively selected cell fraction containing the $\mathrm{CD} 4^{+} \mathrm{CD} 25^{+} \mathrm{CD} 127^{\mathrm{dim} /-}$ regulatory $\mathrm{T}$ cells was separated over a second, new column. Depletion of non-CD4 ${ }^{+}$and CD127 high cells was performed on an LD Column. The subsequent positive selection of $\mathrm{CD} 4^{+} \mathrm{CD} 25^{+} \mathrm{CD} 127^{\mathrm{dim} /-} \mathrm{T}$ cells was performed on two MS Columns.

RNA extraction and cDNA synthesis. A total RNA from $\mathrm{T}$ regulatory cells $\left(\mathrm{CD} 4^{+} \mathrm{CD} 25^{+} \mathrm{CD} 127^{\mathrm{dim} /-}\right.$ ) was isolated and purified using RNeasy Mini Kit (Qiagen) following the manufacturer's protocol. RNA integrity was verified by $1.5 \%$ agarose gel electrophoresis/ethidium bromide staining and $\mathrm{OD}_{260 / 280}$ absorbance ratio $>1.95$. One microgram of total RNA was used to prepare cDNA. cDNA synthesis was performed using SuperScript ${ }^{\mathrm{TM}}$ First-Strand Synthesis System for RT-PCR (Invitrogen) according to the manufacturer's instructions in the MJ Research Thermal Cycler (Model PTC-200, Watertown, MA, USA).

Real-time PCR. The levels of transcripts were measured by real-time PCR using human genes QuantiTect Hs_IL7R_1_SG Assay (Qiagen) and QuantiTect Hs_GAPDH Assay (Qiagen) as a normalizer. The names and symbols of assessed genes are listed in Table 2. Real-time PCR was performed in duplicate in $20 \mu \mathrm{l}$ using the QuantiTect SYBR Green PCR Master Mix (Qiagen) following the manufacturer's instructions and carried out in the Chromo4 Real-Time PCR Detector (BIO-RAD, USA). The thermal cycling conditions included an initial activation step at $95^{\circ} \mathrm{C}$ for $15 \mathrm{~min}$, followed by 40 cycles of denaturation, annealing and amplification $\left(94^{\circ} \mathrm{C}\right.$ for $15 \mathrm{~s}, 55^{\circ} \mathrm{C}$ for $30 \mathrm{~s}, 72^{\circ} \mathrm{C}$ for $30 \mathrm{~s}$ ). At the end of the amplification phase a melting curve analysis was carried out on the product formed. The fluorescent data collection was performed during the annealing step. A standard curve construction was generated employing a serial of four dilutions of cDNA of a control group sample in reaction with the house- 
Table 2. Names, symbols, Ids and presence/absence of genes in CD4+CD25+CD127low cells.

$(+$, the mRNA present in $100 \%$ of the samples, $+/-$, the mRNA present in less than $25 \%$ of the probes,,- the mRNA present in less than $10 \%$ of the probes).

\begin{tabular}{|c|c|c|c|}
\hline Gene symbol, alias & Gene name & Assay ID & Presence in $\mathrm{T}$ reg cells \\
\hline & Transcription factors: & & \\
\hline FoxP3 & forkhead box P3 & NM_001114377 & + \\
\hline SOCS2 & suppressor of cytokine signaling 2 (SOCS2) & NM_003877 & + \\
\hline SOCS3 & suppressor of cytokine signaling 3 & NM_003955 & + \\
\hline STAT1 & signal transducer and activator of transcription 1 & NM_007315 & + \\
\hline STAT3 & signal transducer and activator of transcription 3 & NM_003150 & + \\
\hline SMAD3 & SMAD family member 3 & NM_005902 & + \\
\hline \multirow[t]{2}{*}{ T-box 21} & T-box 21 (TBX21) & NM_013351 & + \\
\hline & Critical Treg molecules: & & \\
\hline$C D 25$ & interleukin 2 receptor, alpha (IL2RA) & NM_000417 & + \\
\hline CD127 & interleukin 7 receptor (IL7R) & NM_002185 & + \\
\hline GITR & TNF-R superfamily, member 18 (TNFRSF18) & NM_004195 & + \\
\hline CTLA-4 & cytotoxic T-lymphocyte-associated protein 4 & NM_001037631 & + \\
\hline \multirow[t]{2}{*}{ ICOS } & inducible T-cell co-stimulator & NM_012092 & + \\
\hline & Cytokines /chemokines and their receptors: & & \\
\hline IL-10RA & interleukin 10 receptor, alpha & NM_001558 & + \\
\hline$I L-12 A$ & interleukin $12 \mathrm{~A}$ & NM_000882 & + \\
\hline$I L-12 B$ & interleukin $12 \mathrm{~B}$ & NM_002187 & - \\
\hline$I L-17 A$ & interleukin 17A (IL17A) & NM_002190 & $+/-$ \\
\hline IL-21 & interleukin 21 & NM_021803 & + \\
\hline$I L-23 A$ & interleukin 23 alpha subunit p19 & NM_016584 & + \\
\hline IL-27 & interleukin 27 & NM_145659 & + \\
\hline IL-35 (EBI3) & Epstein-Barr virus induced gene 3 & NM_005755 & $+/-$ \\
\hline TGF-BR1 & transforming growth factor, beta receptor I & NM_004612 & + \\
\hline TGF-BR2 & transforming growth factor, beta receptor II & NM_001024847 & + \\
\hline CCL22 & chemokine (C-C motif) ligand 22 & NM_002990 & - \\
\hline$I L-8 R A / C X C R 1$ & interleukin 8 receptor, alpha & NM_000634 & + \\
\hline
\end{tabular}

keeping gene, GAPDH. Based on these curves, the levels of total chosen gene transcripts were calculated after the normalization of chosen gene product to GAPDH. The value of CT was determined by the first cycle number at which fluorescence was greater than the set threshold value. To calculate our data, according to Livak and Schmittgen (2001), we used the comparative CT method for relative quantification i.e. $2^{-\Delta \Delta C T}$ method.

Statistical analysis. The results from flow cytometry and real-time RT-PCR were entered into the database in Microsoft Access 2007 and after the completion transferred and analysed in Statistica 8.0 for Windows (StatSoft, Poland) and GraphPad Prism 5.0 (GraphPad Software, USA). Due to asymmetric data distribution (Kolmogorov-Smirnov and Shapiro-Wilk tests) non-parametric tests were used. The results in the examined and control groups were compared using Mann-Whitney U-test. The correlation between the clinical parameters and flow cytometry/real time PCR results were assessed with Spearman's Rank Correlation Test. P-values less than 0.05 were considered as significant. The graphs were prepared in GraphPad Prism 5.0. The data are presented as me- dian in tables and median and 25th-75th percentiles in figures.

\section{RESULTS}

\section{Alterations in the percentages of $\mathrm{T}$ regulatory cells in children with type 1 diabetes}

There were no differences in WBC (white blood cells) and lymphocytosis (both count and percentage) between examined and control patients (respectively: WBC: 6.1 vs. 6.3 G/1, lymphocyte count: 2.3 vs. $2.1 \mathrm{G} / 1$, lymphocyte percentage: 36 vs. $38 \%$, $P>0.05$ ). The frequency (and absolute count) of $\mathrm{CD}^{+}$ cells in children with T1DM was similar to that obtained in the control group (respectively: $37.0 \%$ vs. $36.0 \%, 0.90 \mathrm{G} / 1$ vs. $0.85 \mathrm{G} / \mathrm{l})$. We noted significantly lower percentages of $\mathrm{CD} 4^{+} \mathrm{CD} 25^{\text {high }}$ cells in the peripheral blood of children with T1DM compared to the control patients ( 2.4 vs. $4.0 \%, P=0.03$ ). A similar difference which was not statistically significant concerned the $\mathrm{CD} 4^{+} \mathrm{CD} 127^{\mathrm{dim} /-}$ subpopula- 


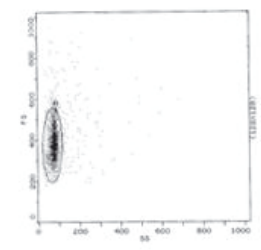

ת

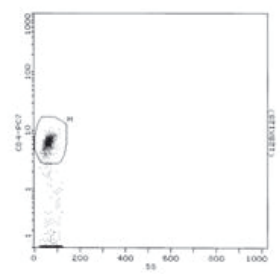

ת

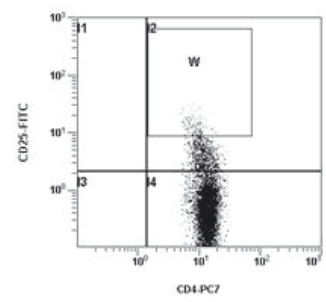

תู

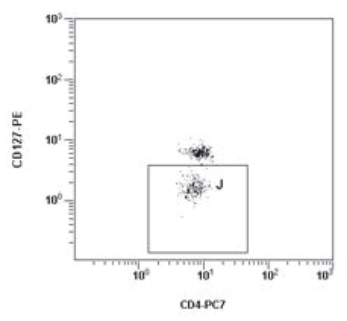

CD4+/CD25high/CD127low/cells

Figure 1. An example of flow cytometry result showing the method for the assessment of CD4 ${ }^{+}$CD25 ${ }^{\text {high }} C D 127^{\text {low } /-}$ cells.

tion (12.6 vs. $17.6 \%, P>0.05)$. The percentages of $\mathrm{CD} 4{ }^{+} \mathrm{CD} 25^{\text {high }} \mathrm{CD} 127^{\mathrm{dim} /-}$ were very low and did not differ between T1DM and control children $(0.54 \%$ vs. $0.59 \%, P>0.05)$. An example of the flow cytometry result in one representative sample is shown in Fig. 1. The comparison of the results obtained from flow cytometry concerning the assessed $\mathrm{T}$ cell subpopulations is presented in Fig. 2.

There was no significant relationship between age, duration of the disease, symptoms before the diagnosis or clinical status and results from flow cytometry.

\section{Disturbances in mRNA levels in $\mathrm{T}$ regulatory cells}

Concurrently with the flow cytometric assessment of Tregs we separated $\mathrm{CD} 44^{+} \mathrm{CD} 25^{+} \mathrm{CD} 127^{\text {low }}$ cells for real-time PCR analysis - an example in Fig. 3. The purity of Treg separation was always

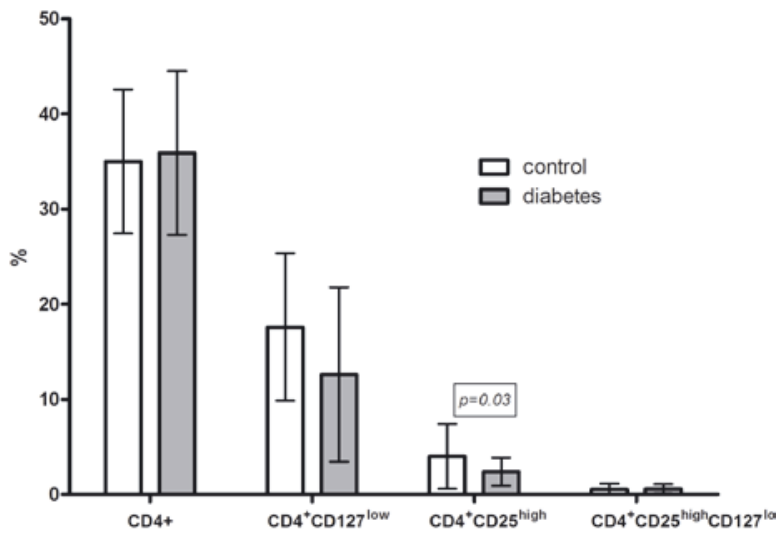

Figure 2. The percentages of $\mathrm{T}$ cell subpopulations in control and diabetic children.

The absolute count and percentages of $\mathrm{CD} 4^{+}$, $\mathrm{CD} 4^{+} \mathrm{CD} 127^{\text {low }}-$ and $\mathrm{CD} 4^{+} \mathrm{CD} 25^{\text {high }} \mathrm{CD} 127^{\text {low }}-$ cells did not differ between examined and control groups. The only significant difference concerned the $\mathrm{CD} 44^{+} \mathrm{CD} 25^{\text {high }}$ subpopulation.

greater than $90 \%$ as assessed in flow cytometer with monoclonal antibodies. Out of the 24 assessed with real-time RT-PCR genes, mRNAs for 20 i.e. $83.3 \%$ were present in all the examined samples (see Table 2). mRNA for IL-12B was not found in any Treg isolate, CCL22, IL-17A, and EBI3 (IL-35) were detected at low levels in: $8.3 \%, 13.3 \%$ and $18.3 \%$ of the samples, respectively.

The results concerning mRNA expression in $\mathrm{CD} 4^{+} \mathrm{CD} 25^{+} \mathrm{CD} 127^{\text {low }}$ cells are presented in Table 3 and shown in Fig. 4. The real-time PCR analysis showed no differences in the mRNA levels of transcription factor FoxP3 in Treg cells in the examined and control groups (0.084 vs. 0.102, $P>0.05)$. Similarly, we did not observe any statistically significant differences between the healthy and diabetic children in mRNA expression for IL-7R (CD127), IL-8RA, IL10RA, IL-12A, IL-2RA (CD25), IL-21, STAT1, STAT3,

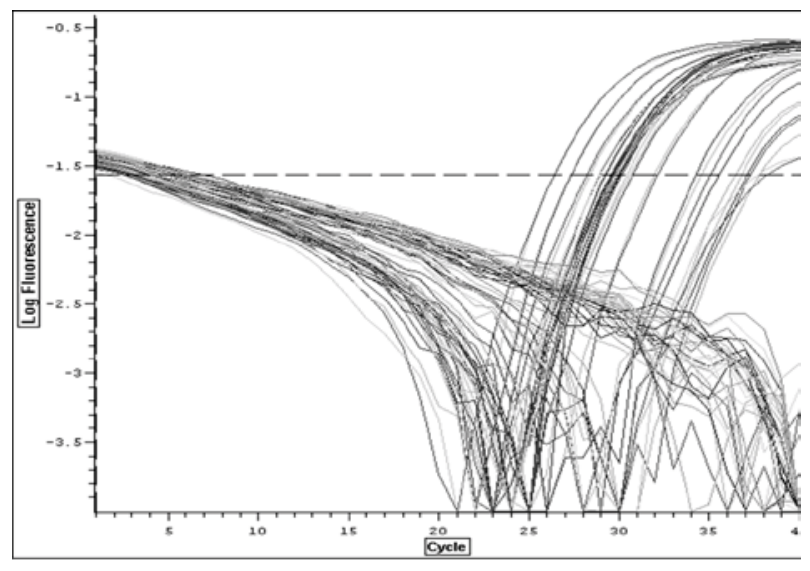

Figure 3. The amplification profiles of CTLA-4 mRNA present in the examined samples. 
Table 3. Results: the mRNA levels of assessed genes in the separated $\mathrm{CD} 4^{+} \mathrm{CD} 25^{+} \mathrm{CD} 127^{-/ \text {low }}$ cells in control children and patients with type 1 diabetes $\left(2^{\wedge-\Delta \Delta C T}\right.$ : median values).

The statistically significant diferences are bolded. ns, not significant

\begin{tabular}{|c|c|c|c|}
\hline Gene symbol & Control patients & Children with T1DM & Statistical analysis \\
\hline \multicolumn{4}{|c|}{ Transcription factors: } \\
\hline FoxP3 & 0.084 & 0.102 & ns \\
\hline SOCS2 & 0.0008 & 0.0008 & ns \\
\hline SOCS3 & 0.042 & 0.051 & ns \\
\hline STAT1 & 0.071 & 0.074 & ns \\
\hline STAT3 & 0.017 & 0.017 & ns \\
\hline SMAD3 & 0.071 & 0.035 & $P<0.05$ \\
\hline T-box 21 & 0.007 & 0.006 & ns \\
\hline \multicolumn{4}{|c|}{ Critical Treg molecules: } \\
\hline$C D 25$ & 0.036 & 0.037 & ns \\
\hline CD127 & 0.158 & 0.205 & ns \\
\hline GITR & 0.201 & 0.111 & $P<0.05$ \\
\hline CTLA-4 & 0.250 & 0.170 & $P=0.05$ \\
\hline ICOS & 0.002 & 0.0005 & $P=0.01$ \\
\hline \multicolumn{4}{|c|}{ Cytokines /chemokines and their receptors: } \\
\hline$I L-10 R A$ & 0.291 & 0.298 & ns \\
\hline$I L-12 A$ & 0.008 & 0.007 & ns \\
\hline$I L-21$ & 0.0001 & 0.0001 & ns \\
\hline$I L-23 A$ & 0.180 & 0.115 & $P<0.05$ \\
\hline$I L-27$ & 0.024 & 0.001 & $P<0.05$ \\
\hline TGF-BR1 & 0.014 & 0.012 & ns \\
\hline TGF-BR2 & 0.069 & 0.084 & ns \\
\hline$I L-8 R A / C X C R 1$ & 0.03 & 0.04 & ns \\
\hline
\end{tabular}

SOCS2, SOCS3, TGF- $\beta 1-R 1$, TGF- $\beta-R 2$ and TBX-21 genes. Interestingly the mRNA level for CTLA-4, IL23, IL-27, ICOS1, SMAD3 and GITR were lower in Treg cells of the children with diabetes in comparison with control patients. However, the difference concerning CTLA-4 was not statistically significant $(P=0.05)$. There were no genes expressed in higher amounts in Tregs of the diabetic children compared to the controls.

\section{DISCUSSION}

In recent years there has been a growing interest in $\mathrm{T}$ regulatory cells as being an important point in autoimmune responses. In order to estimate the possible role of $\mathrm{T}$ regulatory cells in the pathogenesis of autoimmune diabetes we assessed the percentages of $\mathrm{CD} 4^{+} \mathrm{CD} 25^{\text {high }} \mathrm{CD} 127^{\text {low }}$ cells in the peripheral blood of children with newly diagnosed T1DM. Furthermore, to evaluate the possible expressional dysregulation of elements important in Tregs function the transcript levels of chosen genes were determined in children with T1DM and compared with those from non-diabetic subjects. We did not observe any significant differences in the percentages of $\mathrm{CD}^{+} \mathrm{CD} 25^{\text {high }} \mathrm{CD} 127^{\text {low }}$ cells between the examined and control groups, but identified some defects in gene expression including diminished mRNA expression of ICOS, GITR and CTLA-4 molecules in T regulatory cells of children with type 1 diabetes. Those abnormalities could be the result of an immunologic imbalance accompanying the onset of diabetes.

The previous studies performed e.g. by Kukreja et al. (2002) reported low numbers of $\mathrm{CD} 4{ }^{+} \mathrm{CD} 25^{+}$ $\mathrm{T}$ cells in T1DM. This experiment was conducted before establishing the importance of FoxP3 and IL-7 receptor (CD127) in the assessment of Tregs. Our results concerning the significant differences in $\mathrm{CD} 44^{+} \mathrm{CD} 25^{\text {high }}$ subpopulation confirm those early findings. Later it was shown by many authors that levels of Tregs in patients with newly diagnosed T1DM are normal (Lindley et al., 2005; Liu et al., 2006; Brusko et al., 2007). In our group of patients the percentages of $\mathrm{CD} 4^{+} \mathrm{CD} 25^{+} \mathrm{CD} 127^{\text {low }}-$ in diabetic and healthy children were low about $0.6 \%$. In spite of the low percentage and number Putnam et al. (2009) have successfully isolated those cells with the use of fluorescence-activated cell sorting (FACS) from diabetic and control subjects. These cells were fully functional and feasible for in vitro expansion. Interestingly, Liu et al. (2006) postulate that Tregs can be defined only by the expression of CD4 and CD127, not necessarily by CD25 high expression. The majority of $\mathrm{CD} 4^{+} \mathrm{CD} 127^{\text {low/- }}$ cells express FoxP3, 
FoxP3
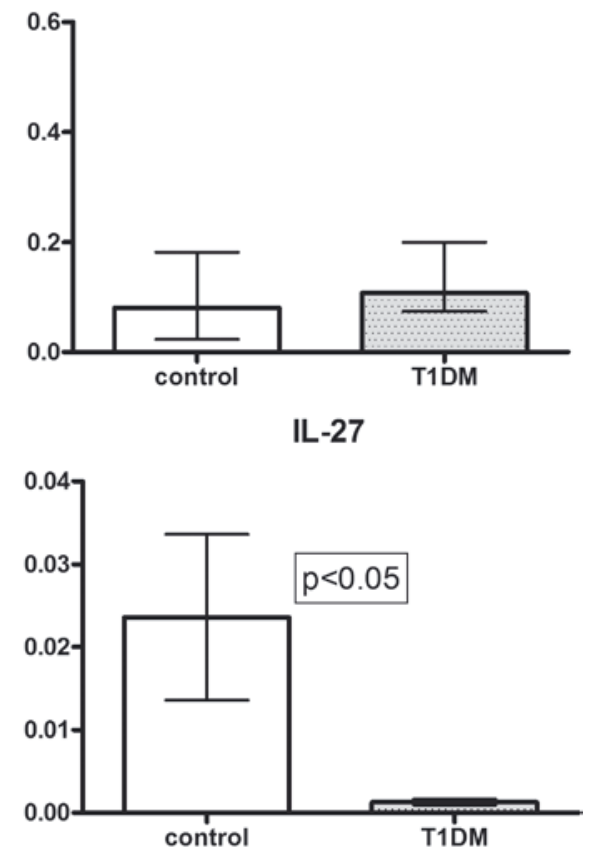

GITR

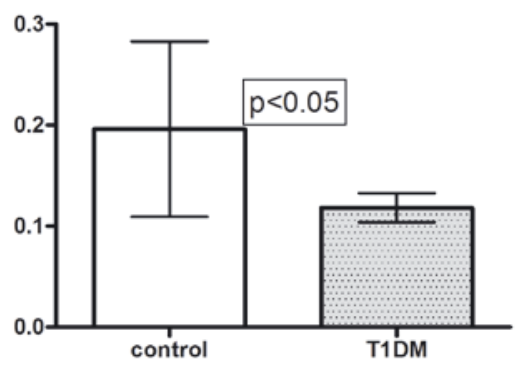

CTLA-4

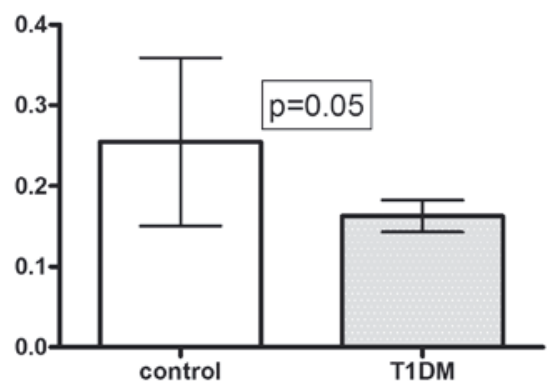

ICOS1

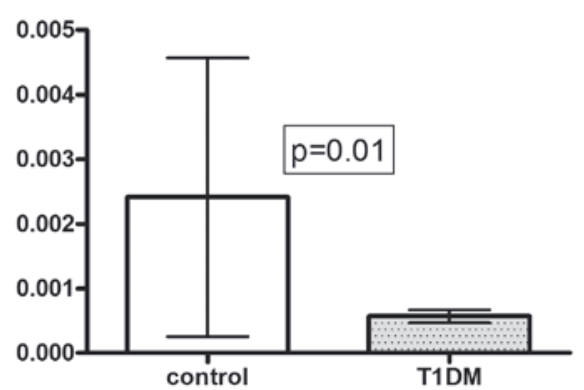

SMAD3

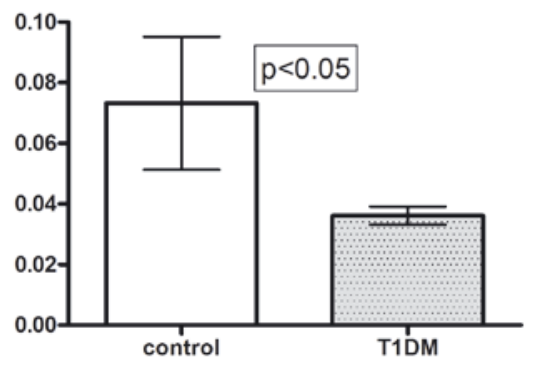

Figure 4. The comparison of the real-time PCR results concerning chosen genes in T regulatory cells.

The mRNA levels of FoxP3 were similar in the diabetic (T1DM) and healthy patients (control). The expression of CTLA4, IL-27, ICOS1, GITR and SMAD3 in Tregs of children with T1DM are lower than in age-matched, control children. The results are presented as median and 25 th-75th percentile.

are anergic and possess strong suppressive function. However, according to the authors of that report the best combination of cell surface markers for Treg separation is $\mathrm{CD} 4{ }^{+} \mathrm{CD} 25^{\text {high }} \mathrm{CD} 127^{\text {low/- }}$, which accounts for about $80 \%$ of $\mathrm{FoxP}^{+}$cells. In our study the CD127 low/- cells accounted for $10-20 \%$ of $\mathrm{CD} 4^{+}$ cells. This finding is similar to that obtained by Liu et al. (2006).

It remains unclear whether mice or humans are deficient in the numbers of Tregs, but there is a consensus that they do have a deficit in their function, mainly presented as an impaired suppressory activity (Lindley et al., 2005). The defective suppressory function of Tregs in patients with T1DM is not only present at the onset but also in a long-standing ( $>3$ years duration) disease (Lawson et al., 2008). Interestingly, no differences in FoxP3 or CD127 expression are observed that could account for this phenomenon in this group of patients. FoxP3,
CTLA-4, GITR and ICOS belong to the most intensively examined transcription factors and molecules important in Treg function. Similar to us, Kivling et al. (2008) also did not find differences in FoxP3 expression between diabetic and reference children. However the expression of FoxP3 at mRNA level in mononuclear cells of children with celiac disease (CD) was higher than in patients with T1DM (Kivling et al., 2008). These results are quite interesting as both T1DM and CD are considered as autoimmune $\mathrm{Th}_{1}$-mediated diseases. However, recently one group using the validated protocol for FoxP3 assessment with flow cytometry showed an increased FoxP3 expression in patients with T1DM (Grant et al., 2009). In contrast to ours, this experiment was performed at the protein and not mRNA level.

CTLA-4, a negative regulator of T-cell activation is also involved in Tregs immune-suppressive function (Read et al., 2000). In an adoptive transfer 
model of diabetes the CTLA- 4 deficient Tregs were unable to regulate diabetes (Schmidt et al., 2009). This confirms that CTLA-4 is required for the proper function of Tregs and suppression of autoimmune response against pancreatic-beta cells. In contrast to our findings, Lindley et al. (2005) found a higher proportion of Tregs with CTLA-4 and CD69 co-expression in patients with T1DM. Thus, it is unclear whether the lower expression of CTLA-4 found in our experiment can be interpreted as an increased or decreased regulatory capacity of Tregs. GITR whose expression was reduced in Treg cells of our patients is also involved in self-tolerance maintained by Tregs (Shimizu et al., 2002). Another member of CD28/CTLA-4 family ICOS - is thought to influence the function of $\mathrm{T}$ cells. The absence of ICOS inhibits the function of Tregs and exacerbates the symptoms of autoimmune diseases including diabetes (Herman et al., 2004). Interestingly the deletion of ICOS resulted in a decrease of $\mathrm{Th}_{1}$ cells but no change in Tregs was observed (Hawiger et al., 2008). In authors' opinion ICOS is important for the development of insulitis but probably it is not Tregs that are involved in this process. In another study, the expression levels of FoxP3, CTLA-4, CD28 and ICOS in mononuclear and $\mathrm{CD}^{+}$cells of patients with T1DM were comparable to the controls (Tsutsumi et al., 2006). Only the PD-1 gene expression levels were lower in the T1DM group but this gene was not assessed in our experiment. In an interesting experiment the expression of FoxP3, CTLA-4 and ICOS in patients treated with insulin was higher compared to the patients with T1DM before any treatment (Tiittanen et al., 2006). Nethertheless, one cannot exclude the influence of ketoacidosis and metabolic imbalance on immune system function in patients admitted to the hospital. The time of the assessment of immune system in patients with T1DM is not established. It is possible that changes in $\mathrm{T}$ regulatory cells may contribute to the clinical remission of the disease. This experiment was performed at mRNA level like ours, but on mononuclear cells not separated $\mathrm{T}$ regulatory cells.

Pro- and anti-inflammatory cytokines play a pathogenic role in autoimmunological diseases like diabetes mellitus, rheumatoid arthritis and systemic lupus erythematosus. The underlying mechanism of the self-destruction are not fully understood. TGF- $\beta$ is a cytokine involved in controlling various immune functions including the proliferation and activation of important cell subtypes. We noted lower, but not significantly, expression of TGF- $\beta 1$ receptors 1 and 2 in Tregs in T1DM patients compared to control children. In another study a decline in active membranebound TGF- $\beta$ led to the onset of diabetes (Gregg et al., 2004). A newly discovered subset of $T$ regulatory cells, $\mathrm{CD} 9^{+} \mathrm{CD} 4^{+} \mathrm{CD} 25^{-}$, FoxP3 negative, IL-10 nega- tive, was also characterized by membrane-bound TGF- $\beta 1$ and CD122 expression confirming the role of this immunosuppressive cytokine in Treg function (Han et al., 2009). Tregs and increased TGF- $\beta 1$ are also involved in the effective immunotherapy of T1DM e.g. with complete Freund's adjuvant (Tian et al., 2009).

The importance of another cytokine i.e. interleukin-21 in the pathogenesis of T1DM was postulated recently by Clough et al. (2008). In the NOD mouse model authors showed elevated IL-21 production during the onset of diabetes, however, this cytokine was not produced by Tregs but $\mathrm{CD} 4^{+} \mathrm{CD} 25^{-}$ cells. IL-21 was detected in our samples only in very small amounts. The lack of mRNA for EBI3, the element of IL-35, in T regulatory cells, found in our experiment confirms the other authors' findings that EBI3 is not expressed in human Tregs, in contrast to mouse cells (Bardel et al., 2008).

The role of suppressor of cytokine signalling (SOCS) family proteins, negative regulators of the JAK-STAT pathway has not been clarified in diabetes. These proteins have multiple biological functions and act as a potent negative regulators of cytokine signalling. The mRNA expression of SOCS-3 and -5 (but not 1) was positively correlated with expression of FoxP3 and T-bet in the peripheral blood of children with allergic sensitization (Daegelmann et al., 2008). We did not find this correlation. SOCS-2 gene was down-regulated in mononuclear cells of patients with rheumatoid arthritis treated with TNF- $\alpha$-blocking agent but not with systemic lupus erythematosus (Tsao et al., 2008). Probably the TNF- $\alpha$ mechanism of action includes the alterations in SOCS-2 gene expression.

The down-regulation of SMAD3, IL-23A, IL-27 and STAT-1 and -3 (not statistically significant) in Tregs from T1DM patients can also confirm the diminished function of those cells. Some authors showed that the FoxP3 expression is facilitated by IL-27 by two mechanisms including STAT-1 and TGF- $\beta$ (Ouaked et al., 2009). The others regard IL-27 as a negative regulator of Tregs (Huber et al., 2008). Xiao et al. (2008) showed that the vitamin A metabolite all trans-retinoic acid (ATRA), a drug used in some autoimmune diseases, enhances the FoxP3 expression by SMAD-3, IL-23R, IL-6R and TGF- $\beta$ signaling. In another experiment ATRA reduced T-bet and STAT4 expression in T-cells resulting in the inhibition of diabetes (Van et al., 2009). T-bet, a key transcription factor directing $\mathrm{T}$ helper type 1 inflammatory responses, is regulated via STAT- 1 and 5 pathways. T-cells from children with T1DM showed impaired induction of Foxp3, ICOS and NFATc2 after the culture in type 1 cytokine milieu but no differences were observed in T-bet and GATA-3 expression (Honkanen et al., 2008). In Honkanen's opinion 
this effect may contribute to the pathogenesis of the disease. Selectively targeting genes expressed in Tregs could be important strategies in autoimmune diseases. We believe that future efforts should be directed toward the identification of factors influencing the altered expression of those genes in Treg cells for therapeutic interventions.

Our study demonstrated some disturbances in gene expression in $\mathrm{T}$ regulatory cells present in peripheral blood of children with type 1 diabetes. The results are of considerable interest for the development of immunotherapeutic strategies in this incurable autoimmune disease. A major advance in elucidating the function of Tregs would be the introduction of novel therapies that could re-establish tolerance to the autoantigens. Autoreactive $\mathrm{T}$ cells that mediate islet cell destruction can be manipulated by the administration of $\mathrm{T}$ regulatory cells. The first report from a mouse model are encouraging (Brusko \& Bluestone, 2008). For example, the treatment with $\mathrm{CD} 4{ }^{+} \mathrm{CD} 62 \mathrm{~L}^{+} \mathrm{T}$ regulatory cells led to the reversion of type 1 diabetes in NOD mice (Zhao et al., 2009).

In our view, the expression of chosen genes was performed in $\mathrm{CD} 4^{+} \mathrm{CD} 25^{+} \mathrm{CD} 127^{-}$cells for the first time. In the peripheral blood of the healthy children only about $0.6 \%$ of lymphocytes possess this phenotype. As the high purity of the separation is very difficult to obtain, the population studied was small and the further studies are required to confirm our preliminary findings. Additional experiments are necessary to explain the mechanism by which Tregs carry out their suppressive function, including the role for IL-10, TGF- $\beta$, CTLA-4, ICOS, IL-35 and many other cytokines and molecules. The results from our and other laboratories should help to elucidate the mechanisms involved in the pathogenesis of type 1 diabetes. Clinically relevant agents or methods that could induce immune tolerance may represent an interesting approach in the treatment of autoimmune diseases.

\section{CONCLUSION}

To summarize, we found disturbances in gene expression at mRNA level in T regulatory cells separated from children with type 1 diabetes. These results including low amounts of mRNA for critical molecules like ICOS, CTLA-4 and GITR could contribute to their defective function in autoimmune diseases. Our findings may be used for providing new strategies for the treatment of this incurable disease.

\section{REFERENCES}

American Diabetes Association (2008) Diagnosis and classification of diabetes mellitus. Diabetes Care 31: 55-60.
Bardel E, Larousserie F, Charlot-Rabiega P, CoulombL'Hermine A, Devergne O (2008) Human CD4 $4^{+}$CD25 $5^{+}$ $\mathrm{FoxP}^{+}$regulatory $\mathrm{T}$ cells do not constitutively express IL-35. J Immunol 181: 6898-6905.

Bluestone JA, Tang Q, Sedwick CE (2008) T regulatory cells in autoimmune diabetes: past challenges, future prospects. J Clin Immunol 28: 677-684.

Brusko T, Bluestone J (2008) Clinical application of regulatory $\mathrm{T}$ cells for treatment of type 1 diabetes and transplantation. Eur J Immunol 38: 931-934.

Brusko T, Wasserfall C, McGrail K, Schatz R, Viener HL, Schatz D, Haller M, Rockell J, Gottlieb P, Clare-Salzer M, Atkinson M (2007) No alterations in the frequency of FoxP3 ${ }^{+}$regulatory T-cells in type 1 diabetes. Diabetes 56: 604-612.

Chen Z, Laurence A, Kanno Y, Pacher-Zavisin M, Zhu BM, Tato C, Yoshimura A, Hennighausen L, O'Shea JJ (2006) Selective regulatory function of Socs3 in the formation of IL-17-secreting T cells. Proc Natl Acad Sci USA 103: 8137-8142.

Clough LE, Wang CJ, Schmidt EM, Booth G, Hou TZ, Ryan GA, Walker LS (2008) Release from regulatory T cell-mediated suppression during the onset of tissuespecific autoimmunity is associated with elevated IL21. J Immunol 180: 5393-5401.

Daegelmann C, Harberth G, Roder S, Herbarth O, Giese T, Kramer U, Behrendt $\mathrm{H}$, Borte $\mathrm{M}$, Heinrich J, Emmrich F, Lehmann I, group Ls (2008) Association between suppressors of cytokine signalling, T-helper type 1/Thelper type 2 balance and allergic sensitization in children. Clin Exp Allergy 38: 438-448.

Fife BT, Bluestone JA (2008) Control of peripheral T-cell tolerance and autoimmunity via the CTLA-4 and PD-1 pathways. Immunol Rev 224: 166-182.

Friedline RH, Brown DS, Nguyen H, Kornfeld H, Lee J, Zhang Y, Appleby M, Der SD, Kang J, Chambers CA (2009) CD4 ${ }^{+}$regulatory T cells require CTLA-4 for the maintenance of systemic tolerance. J Exp Med 206: 421434.

Grant J, Bourcier K, Wallace S, Pan D, Conway A, SeyfertMargolis V, Wallace PK (2009) Validated protocol for FoxP3 reveals increased expression in type 1 diabetes patients. Cytometry B Clin Cytom 76: 69-78.

Gregg RK, Jain R, Schoenleber SJ, Divekar R, Bell JJ, Lee $\mathrm{HH}, \mathrm{Yu}$ P, Zaghouani H (2004) A sudden decline in active membrane-bound TGF-beta impairs both $\mathrm{T}$ regulatory cell function and protection against autoimmune diabetes. J Immunol 173: 7308-7316.

Han Y, Guo Q, Zhang M, Chen Z, Cao X (2009) $\mathrm{CD} 9^{+} \mathrm{CD} 4^{+} \mathrm{CD} 25^{-} \mathrm{T}$ cells, a new subset of regulatory $\mathrm{T}$ cells, suppress $\mathrm{T}$ cell proliferation through membranebound TGF-beta 1. J Immunol 182: 111-120.

Hawiger D, Tran E, Du W, Booth CJ, Wen L, Dong C, Flavell RA (2008) ICOS mediates the development of insulin-dependent diabetes mellitus in nonobese diabetic mice. J Immunol 180: 3140-3147.

Herman AE, Freeman GJ, Mathis D, Benoist C (2004) $\mathrm{CD} 4^{+} \mathrm{CD} 25^{+} \mathrm{T}$ regulatory cells dependent on ICOS promote regulation of effector cells in the prediabetic lesion. J Exp Med 199: 1479-1489.

Honkanen J, Skarsvik S, Knip M, Vaarala O (2008) Poor in vitro induction of FOXP3 and ICOS in type 1 cytokine environment activated T-cells from children with type 1 diabetes. Diabetes Metab Res Rev 24: 635-641.

Huber M, Steinwald V, Guralnik A, Brüstle A, Kleemann P, Rosenplänter C, Decker T, Lohoff M (2008) IL-27 inhibits the development of regulatory $\mathrm{T}$ cells via STAT3. Int Immunol 20: 223-234. 
Kivling A, Nilsson L, Fälth-Magnusson K, Söllvander S, Johanson C, Faresjö M (2008) Diverse FOXP3 expression in children with type 1 diabetes and celiac disease. Ann NY Acad Sci 1150: 273-277.

Kukreja A, Cost G, Marker J, Zhang C, Sun Z, Lin-Su K, Ten S, Sanz M, Exley M, Wilson B, Porcelli S, Maclaren N (2002) Multiple immuno-regulatory defects in type-1 diabetes. J Clin Invest 109: 131-140.

Lawson JM, Tremble J, Dayan C, Beyan H, Leslie RD, Peakman M, Tree TI (2008) Increased resistance to $\mathrm{CD} 4^{+} \mathrm{CD} 25^{\text {hi }}$ regulatory $\mathrm{T}$ cell-mediated suppression in patients with type 1 diabetes. Clin Exp Immunol 154: 353-359.

Lindley S, Dayan CM, Bishop A, Roep BO, Peakman M, Tree TI (2005) Defective suppressor function in CD4(+)CD25(+) T-cells from patients with type 1 diabetes. Diabetes 54: 92-99.

Liu W, Putnam AL, Xu-Yu Z, Szot GL, Lee MR, Zhu S, Gottlieb PA, Kapranov P, Gingeras TR, Fazekas de St Groth B, Clayberger C, Soper DM, Ziegler SF, Bluestone JA (2006) CD127 expression inversely correlates with FoxP3 and suppressive function of human CD4+ T reg cells. J Exp Med 203: 1701-1711.

Livak KJ, Schmittgen TD (2001) Analysis of relative gene expression data using real-time quantitative PCR and the 2-ddCT method. Methods 25: 402-408.

Matsumura Y, Kobayashi T, Ichiyama K, Yoshida R, Hashimoto M, Takimoto T, Tanaka K, Chinen T, Shichita T, Wyss-Coray T, Sato K, Yoshimura A (2007) Selective expansion of Foxp3-positive regulatory $\mathrm{T}$ cells and immunosuppression by suppressors of cytokine signaling 3-deficient dendritic cells. J Immunol 179: 2170-2179.

Ouaked N, Mantel PY, Bassin C, Burgler S, Siegmund K, Akdis CA, Schmidt-Weber CB (2009) Regulation of the foxp3 gene by the Th1 cytokines: the role of IL-27-induced STAT1. J Immunol 182: 1041-1049.

Putnam AL, Brusko TM, Lee MR, Liu W, Szot GL, Ghosh T, Atkinson MA, Bluestone JA (2009) Expansion of human regulatory $\mathrm{T}$ cells from patients with type 1 diabetes. Diabetes 58: 652-662.

Read S, Malmstrom V, Powrie F (2000) Cytotoxic T lymphocyte-associated antigen 4 plays an essential role in the function of $\mathrm{CD} 25^{+} \mathrm{CD} 4^{+}$regulatory cells that control intestinal inflammation. J Exp Med 192: 295-302.

Roncador G, Brown PJ, Maestre L, Hue S, Martínez-Torrecuadrada JL, Ling $\mathrm{KL}$, Pratap S, Toms C, Fox BC, Cerundolo V, Powrie F, Banham AH (2005) Analysis of FOXP3 protein expression in human $\mathrm{CD} 4^{+} \mathrm{CD} 25^{+}$regulatory $\mathrm{T}$ cells at the single-cell level. Eur J Immunol 35: 1681-1691.
Schmidt EM, Wang CJ, Ryan GA, Clough LE, Qureshi OS, Goodall M, Abbas AK, Sharpe AH, Sansom DM, Walker LS (2009) Ctla-4 controls regulatory T cell peripheral homeostasis and is required for suppression of pancreatic islet autoimmunity. J Immunol 182: 274-282.

Seddiki N, Santner-Nanan B, Martinson J, Zaunders J, Sasson S, Landay A, Solomon M, Selby W, Alexander SI, Nanan R, Kelleher A, Fazekas de St Groth B (2006) Expression of interleukin (IL)-2 and IL-7 receptors discriminates between human regulatory and activated $\mathrm{T}$ cells. J Exp Med 203: 1693-1700.

Shimizu J, Yamazaki S, Takahashi T, Ishida Y, Sakaguchi $\mathrm{S}$ (2002) Stimulation of $\mathrm{CD} 25^{+} \mathrm{CD} 4^{+}$regulatory $\mathrm{T}$ cells through GITR breaks immunological self-tolerance. Nat Immunol 3: 135-142.

Tian B, Hao J, Zhang Y, Tian L, Yi H, O'Brien TD, Sutherland DE, Hering BJ, Guo Z (2009) Upregulating $\mathrm{CD}^{+} \mathrm{CD} 25^{+} \mathrm{FoxP}^{+}$regulatory $\mathrm{T}$ cells in pancreatic lymph nodes in diabetic NOD mice by adjuvant immunotherapy. Transplantation 87: 198-206.

Tiittanen M, Huupponen JT, Knip M, Vaarala O (2006) Insulin treatment in patients with type 1 diabetes induces upregulation of regulatory T-cell markers in peripheral blood mononuclear cells stimulated with insulin in vitro. Diabetes 55: 3446-3454.

Tsao JT, Kuo CC, Lin SC (2008) The analysis of CIS, SOCS1, SOSC2 and SOCS3 transcript levels in peripheral blood mononuclear cells of systemic lupus erythematosus and rheumatoid arthritis patients. Clin Exp Med 8: 179-185.

Tsutsumi Y, Jie X, Ihara K, Nomura A, Kanemitsu S, Takada H, Hara T (2006) Phenotypic and genetic analyses of T-cell-mediated immunoregulation in patients with type 1 diabetes. Diabet Med 23: 1145-1150.

Van YH, Lee WH, Ortiz S, Lee MH, Qin HJ, Liu CP (2009) All-trans retinoic acid inhibits type 1 diabetes by $\mathrm{T}$ regulatory (Treg)-dependent suppression of interferongamma-producing T-cells without affecting Th17 cells. Diabetes 58: 146-155.

Xiao S, Jin H, Korn T, Liu SM, Oukka M, Lim B, Kuchroo VK (2008) Retinoic acid increases FoxP3+ regulatory $\mathrm{T}$ cells and inhibits development of Th17 cells by enhancing TGF- $\beta$ driven Smad3 signaling and inhibiting IL-6 and IL-23 receptor expression. J Immunol 181: 2277-2284.

Zhao Y, Lin B, Darflinger R, Zhang Y, Holterman MJ, Skidgel RA (2009) Human cord blood stem cell-modulated regulatory $\mathrm{T}$ lymphocytes reverse the autoimmune-caused type 1 diabetes in nonobese diabetic (NOD) mice. PLoS ONE 4: e4226. 